\title{
EFFECT OF EGGSHELL OSTEOPONTIN PROTEIN ON SKELETAL EMBRYONIC DEVELOPMENT AND HATCHING TRAITS OF DEVELOPED CHICKEN STRAINS
}

\author{
Mona R. M. Ahmed; Wesam A. Fares; E. A. Abdalla; and R. E. Rizk
}

Anim. Prod. Res. Inst., Agric. Res. Center, Egypt

Corresponding Author: Mona R. M. Ahmed; Email: dr_monarefaat@ yahoo.com

Received:17/12/2016 Accepted:26/01/2017

\begin{abstract}
The present study was designed to study the change of shell quality, shell strength, hatching output, calcium (ca) and phosphorus (ph) concentrations in tibia bone for embryos and hatched chicks, bone strength and some related physiological parameters as affected by either chicken strain (Mandarah, M and Gimmizah, G) or osteopontin (OPN) protein in eggshell. Results indicated that $M$ strain surpassed $(p \leq 0.05) G$ one for OPN concentration $(\mathrm{ng} / \mu \mathrm{L})$ in eggshell of fresh eggs, eggshell at hatch, tibia for hatched chicks besides in hatched chick's blood. Egg quality including eggshell weight \%,shell index, shell strength (Newton), eggshell and eggshell membranes thickness (mm) were significantly increased for $\mathrm{M}$ strain compared with those for $\mathrm{G}$ one, whereas egg abnormalities $\%$ and egg weights were significantly $(\mathrm{p} \leq 0.05)$ increased for $\mathrm{G}$ chickens. Moreover, egg weight loss $\%$ during incubation, embryonic mortality $\%$, hatch time (h) and hatch window (h) were significantly diminished for eggs produced from $M$ chickens compared to those for $\mathrm{G}$ one besides, $M$ strain had the higher percentage of hatchability of fertile eggs $(p \leq 0.05)$. Mandarah chickens represented significant increase of ca and ph concentrations compared with $\mathrm{G}$ ones in fresh eggs and eggshell for embryos at days 9 and 15. Mandarah chicks surpassed $(\mathrm{p} \leq 0.05) \mathrm{G}$ ones with respect to plasma ca, $\mathrm{ph}$ and parathyroid hormone. Also, tibia bones for embryos at day 15 and hatched chicks were stronger $(p \leq 0.05)$ for $M$ strain than those for $\mathrm{G}$ one.

The important role of the genes due to chicken strain besides OPN protein in eggshell and embryonic bone could open promising tool for understanding the quality of eggshell and its applications for breeding programs.
\end{abstract}

Keywords: Osteopontin- Eggshell quality- Hatchability- Parathyroid hormone- Bone strength. 


\section{INTRODUCTION}

The most important goal in egg layer breeding is to produce high numbers of good quality eggs (Mahrous et al., 2013). The eggshell is essential for propagation of all avian species, it is a sophisticated structure, whose properties reflect perfectly their crucial functions in reproduction, control gas exchange during development of the chick embryo and provide the calcium for embryonic development (Nys et al., 2004). In order to improve eggshell quality, it is necessary to identify the molecular constituents involved in the mineralization of the eggshell (Pines, 2007). Eggshells are fabricated by combining particular extra cellular matrix macromolecules with crystalline calcite filler while the egg is moving along the oviduct to produce a mineral- organic composite (Arias and Fernandez, 2001). Organic matrix proteins assist in control the mechanical properties of the eggshell (Hincke et al., 2012) and the shape, size and orientation of the calcite crystals are due to the interaction of calcium carbonate and the organic matrix (Dominguez-Vera et al.,2000). Osteopontin (OPN) is a phosphorylated glycoprotein and it is a main eggshell matrix protein (Fernandez et al., 2003). Osteopontin is intimately involved in the regulation of both physiological and pathological mineralization and eggshell calcification process (Hincke et al., 2008). Also, OPN was associated with eggshell fracture toughness (Dunn et al., 2008). Moreover, OPN gene is expressed in skeletal embryonic tissue (Weinreb et al., 1990). Noda and Rodan (1989) found that OPN was regulated by calcitrophic substance such as parathyroid hormone. Also, Sodek et al. (2000) showed that OPN involved in a variety processes including development, immunological response, bone resorption and calcification.

Numerous investigators proved that different strains of laying hen vary significantly in eggshell quality and egg size (Juliet, 2004; and Rizk et al. 2008) shell thickness strength and egg abnormality (Rizk, 1994; and Yuan et al., 2009). Also, chicken strain had a significant effect on hatchability $\%$ and chick weight at hatch (Yousria et al., 2010). Moreover, chicken strain has important effects on some blood criteria (Enaiat et al., 2010). Several publications referred to the importance of the mitotic index as an indicator technique of deep movement for cell population during embryogenesis (Rizk, 1994; and Mona, 2011).

This study is a second part of series researches designed to gain more information regarding the role of osteopontin protein in eggshell quality, bone strength, hatching output, calcification of eggshell and bone, mitotic index and parathyroid hormone focusing on their relation changes with chicken strain.

\section{MATERIALS AND METHODS}

The present experiment was carried out at El-Sabahia Poultry Research Station, Animal Production Research Institute, Agriculture Research Center.

\section{Experimental design:}

One thousand and two hundreds hatching eggs representing two chicken strain (Gimmizah, G and Mandarah, M) aged 46week were used in this study. Six hundred hatching eggs representing each chicken strain after discarding the abnormal eggs were divided into three replicates. All eggs were individually numbered and weighed prior to the beginning of the incubation and incubated in Egyptian made incubator at $99.5^{\circ} \mathrm{F}$ and $55 \% \mathrm{RH}$ during setting phase of incubation. The time of setting eggs in the incubator was recorded for both strains to obtain the hatch time exactly in hours and considered as zero time of experiment. At 18 day (432 hrs) of incubation, the eggs were weighed, candled and those with evidence of living embryos were transferred to hatcher unit and incubated at $99^{\circ} \mathrm{F}$ and $70 \%$ RH. At $0,7,14,18$ days of incubation, all eggs were individually weighed $(\mathrm{gm})$, the percentages of egg 
weight loss were calculated for incubation intervals $\quad(0-7, \quad 8-14, \quad 15-18,0-18)$. Beginning at $456 \mathrm{hrs}$ of incubation and at $12 \mathrm{hrs}$ intervals thereafter the hatcher was opened and chicks had fully emerged from eggs were removed and hatch window was calculated the period of time elapsed from the hatching of the first chick to the hatching of the last one (Decuypere et al., 2001)\}. Body weights (g) for all chicks at the time of removal from the hatcher were recorded and termed as chick weight at pull out. Hatchability of fertile eggs percentage was determined. Eggs that failed to hatch at the end of incubation and having full opportunities for hatch were broken out and then examined with naked eye to estimate embryonic mortalities percentages during the experimental intervals (early) 1-7, (mid) 8-14 and (late) 15-21 days of incubation.

\section{Measurements:-}

Before setting the eggs in the incubator, percentage of abnormal eggs was detected and discarded (rounded, oblonged, wrinkled, thinner eggshell and those with extra calcification, extremely large and small ones).

Three fresh hatched eggs from each replicate representing the two strains were taken to estimate the following parameters: eggs were individually weighed to nearest $0.1 \mathrm{~g}$, egg shape index was determined as the percentage of the greatest width to the greatest length (Romanoff and Romanoff, 1949). Also the shells of broken eggs were weighed without the shell membranes to the nearest $0.1 \mathrm{~g}$ then eggshell weight percentages were calculated. In addition to, eggshell thickness was measured with and without membranes by a micrometer to the nearest $0.01 \mathrm{~mm}$. Eggshell strength (Newton) was estimated by single Radial Immune Diffusion Technique as described by Bennett et al. (1988) with Digital Force Gauge- FGC-50 at Agricultural Engineering Research Institute.

Proteins including osteopontin protein (OPN) were estimated at the Plant
Pathology Research Institute, Central Lab of Biotechnology and analyzed by gel running. The OPN concentration $(\mathrm{ng} / \mu \mathrm{L})$ was estimated in eggshell according to the method of AOAC (1998) and in bones according to the method of AOAC (1955) by Atomic Absorption Spectrometer.

Osteopontin, calcium (ca) and phosphorus (ph) concentrations were measured in eggshell of 3 eggs from each replicate for the two strains for fresh eggshell and at days 9 and 15 of incubation and at hatch. Also the same previous parameters were estimated in embryonic tibia bone at day 15 of incubation.

Blood samples were taken from slaughtered hatched chicks and collected in heparinized tube immediately for measuring OPN protein in the blood, Also, plasma parathyroid hormones (ng/ml), globulin (mg/dl), calcium (mg/dl) phosphorus (mg/dl), glucose $(\mathrm{mg} / \mathrm{dl})$, total lipids $(\mathrm{mg} / \mathrm{dl})$ and cholesterol $(\mathrm{mg} / \mathrm{dl})$ were detected by available commercial diagnostics kits .

Osteopontin, $\mathrm{Ca}$ and $\mathrm{Ph}$ concentrations were measured in tibia bone for the same previous slaughtered hatched chicks.

Tibia breaking strengths (Newton) for tibia of embryos at day 15 and for hatched chicks were measured using an universal material testing machine (H5 0 k-s, Hounsfield Ltd., Surrey, UK) in the laboratory of mechanical properties and test of materials, Faculty of engineering, Ain Shams University according the method of Park et al. (2003).

Developed embryos at day15 of incubation and hatched chicks for each experimental strain were used for determining the mitotic index (MI) as Kinetic parameter of the cell cycle in tibia bone (Overton, 1958). Also, the mitotic index was calculated according the formula of Dondua et al. (1966) which is

Mitotic index $=($ mitotic cells $/$ total number of cells) $\times 100$ 


\section{Statistical analyses:}

Data obtained were statistically analyzed using general linear models (GLM) of SAS (2004). The significant differences among treatment means were tested according to Duncan (1955).

The following model was used

$\mathrm{Y}_{\mathrm{ij}}=\mu+\mathrm{L}_{\mathrm{i}}+\mathrm{e}_{\mathrm{ij}}$

$\mu=$ the overall mean,

$\mathrm{L}_{\mathrm{i}}=$ strain effect,

$\mathrm{e}_{\mathrm{ij}}=$ random error

\section{RESULTS AND DISCUSSION}

\section{Osteopontin protein:}

Data of Table 1 represent osteopontin protein concentration $(\mathrm{ng} / \mu \mathrm{L})$ in eggshell, embryonic tibia and blood of hatched chicks for $G$ and $M$ chicken strains. It appears from data of this table that $M$ strain surpassed $(p \leq 0.05) G$ one for OPN concentration in eggshell of fresh eggs, eggshell at hatch, tibia for hatched chicks besides in hatched chick's blood . Eggshell during incubation at days 9 and 15 and tibia at day 15 of incubation did not represent any statistical differences between experimental chicken strains with respect to OPN concentration. Moreover, it is observed from data of this table the OPN concentrations tended to decrease significantly from fresh eggs towards eggshell at hatch including eggshells at days 9 and 15 of incubation for both experimental chicken strains. Whereas, OPN was significantly $(\mathrm{p} \leq 0.05)$ increased for tibia of hatched chicks compared to those at day 15 of incubation.

The significant decrease of OPN concentration from eggshells of fresh eggs upon eggshell at hatch from both experimental strains is normal as OPN is depleted from eggshell with the advanced growth of embryos. Also OPN increase in the tibia of hatched chicks could be related to the depletion from eggshell as detected through embryonic development. These results of OPN concentration in eggshell, tibia bone and blood of hatched chick's (Table1) are confirmed by different authors. Hincke et al. (2012) found OPN in bone, eggshell and blood and is suggested to be a part of the array of macromolecules contributing to the regulation of eggshell mineralization. Also, Mann and Mann (2013) showed that OPN is a major noncollagen protein in bone.

The results of significant increase of OPN concentration of $M$ chicken strain compared with $\mathrm{G}$ one as shown in Table 1 may be due to genetic differences between both experimental strains. Several investigators found significant differences among local strains of chickens due to genetic causes (Younis and Abd ELGhany, 2003; and Yoursia et al., 2010).

Eggshell quality: Data of Table 2 reveal that the parameters of eggshell quality including eggshell weight (g), eggshell weight $\%$, shell strength (Newton), eggshell index, eggshell thickness (mm) and eggshell membranes thickness (mm) were significantly increased for $M$ strain compared with those for $\mathrm{G}$ one. Whereas, egg abnormalities\% and egg weights were significantly increased for $G$ strain compared to $\mathrm{M}$ one. Varying response of eggshell quality due to chicken strain is presented in the data of Table 2. Genetical differences in eggshell formation characteristic and consequently eggshell quality among chicken breeds and strains are documented by different authors (Juliet, 2004; and Fathi et al., 2010). Moreover, the results reported herein regarding abnormal eggs $\%$ are keeping with that reported by Rizk (1994) who mentioned that eggshell abnormalities for size and shape are caused by different factors such as uniformity and strains.

Data of egg weight increase for $G$ strain compared to $\mathrm{M}$ one are confirmed by previous results of Younis and Abd ELGhany (2003) and Yousria et al. (2010). This increase of egg weight is not accompanied by the increase of eggshell weight and this conclusion is proved by Juliet (2004) as she pointed out that egg weight is more closely associated with albumen weight than with shell weight. 
Different authors found that strain had a significant effect on shell thickness and shell strength (De ketelaere et al., 2002; Yuan et al., 2009; and Yousria et al., 2010). Moreover, several reports came to same conclusion in this paper regarding that larger eggs had thinner shells (Scott and Silversides, 2000). The current results of the increase of eggshell strength with the increase of eggshell thickness are coincided with that previously reported by Juliet (2004) and she added that shell breaking strength is negatively correlated with the percentage of cracks.

Interpretation of the results of abnormal eggs \% increase with the decrease of eggshell thickness and eggshell strength for $\mathrm{G}$ eggs compared to $\mathrm{M}$ ones could be based on the light of OPN decrease for G strain as previously presented in Table 1. Eggshell matrix proteins are thought to influence the structure and mechanical properties of the eggshell (Nys et al., 1999). Jonchere et al. (2010) showed that OPN had major role in mineralization of the eggshell and abnormal expression of OPN in the shell gland is related to abnormalities and cracks in the eggshell. Also, Hincke et al. (2012) revealed that OPN was associated with eggshell fracture toughness.

So, it could be concluded from the present results and the cited information that improvement of eggshell quality for $M$ strain could partially due to the increase of OPN in eggshell and conjugated with the decrease of abnormal eggs and increase in eggshell thickness and strength.

Hatching traits: Data of Table 3 represent that chicken strain had significant influence on egg weight loss \% among different studied incubation periods (0-7, 8-14 and 018 days), embryonic mortalities during early (1-7 days) and late (15-20 days), hatch time (hr), hatch window (hr) and chick weight at hatch (g) as $\mathrm{G}$ chicken strain recorded the significant increase $(p \leq 0.05)$ of those parameters compared to M chicken. Moreover, M strain represented significant increase of hatchability of fertile eggs $(89.08 \%)$ compared to $85.58 \%$ for $\mathrm{G}$ strain. It is obvious from these data that the decrease of hatchability of fertile eggs for $G$ strain is coincided with the increase of all previously mentioned parameters such as egg weight loss \%, embryonic mortality, hatch time and hatch window.

Current results of the significant effects of chicken strain on egg weight loss $\%$ and embryonic mortality are supported by different researchers (Shahein et al., 2009; and Wesam et al., 2015). The significant increase of egg weight loss \% for $\mathrm{G}$ strain compared to $\mathrm{M}$ one could be attributed to the decrease of shell and shell membranes thickness as previously demonstrated in Table 2 . These relations were mentioned by Rizk et al. (2008) and Mona et al. (2016). Data of the increase of embryonic mortalities for $\mathrm{G}$ strain could be explained on the light of the decrease of eggshell and membranes thickness and the increase of egg weight loss. Different researchworkers came to the same conclusion and relations between egg weight loss and embryonic mortalities (Shahein et al., 2009; and Mona et al., 2016). Several researchers supported our notion regarding the influence of chicken strain on hatch time (Brake, 1998; and Christensen et al., 2000). Moreover, Wesam et al. (2015) found that $\mathrm{G}$ chicks were significantly delayed for hatch compared to those for $\mathrm{M}$ ones and this delay could be due to the increase of shell conductance and also due to the precise of pore geometry of the shell as mentioned by Rahn (1981).

Lack of information was found to support the significant increase of hatch window for $\mathrm{G}$ strain compared to $\mathrm{M}$ one. From our point of view the increase of hatch window and the spread of hatched for $G$ chicks over longer time of hatch could be explained on the light of genetical background of strains and change of eggshell conductance which leads to delay the plateau stage of embryonic respiration and consequently the delay of internal pipping start. These relations are in line with that reported by 
Rahn et al. (1979) who found relation between egg size, hatch time and egg conductance.

Results of the significant increase of hatchability for eggs of $\mathrm{M}$ strain compared to $G$ one are in harmony with the results of Rizk et al. (2008) and Yousria et al.(2010) and could be related to the decrease of embryonic mortalities. Krystianiak et al. (2016) showed that high shell porosity lead to excessive water loss \% which results in increased embryo mortality and hatch time and decreased hatchability \%. In addition to, Dohnal et al. (1989) observed a positive correlation between hatchability and thickness and strength of the shell and these results are in line with the current results.

The effect of strain on chick body weight at hatch in the current study added credence to the same conclusion was reported by Suarez et al. (1997) and Shahein (2002). Moreover, the significant increase of the body weight of $\mathrm{G}$ chicks at hatch compared to $\mathrm{M}$ ones could be related to the increase of egg weight as represented in Table 2 . This statement is keeping with that reported by Tona et al. (2004) who showed that egg weight is a dominant factor affecting chick weight at hatch. Also, the increase of weight for $\mathrm{G}$ chicks compared to $\mathrm{M}$ ones is previously documented by Wesam et al. (2015).

Calcium

and

phosphorus

concentrations:Effects of chicken strain on calcium and phosphorus concentrations in eggshell and tibia are shown in Table 4. Mandarah chickens represented significant increase of $\mathrm{Ca}$ and $\mathrm{Ph}$ concentration compared with $G$ ones in fresh eggs and eggshell at days 9 and 15. While, eggshell at hatch and tibia for embryos at day 15 and for hatched chicks did not represent any statistical change between $\mathrm{G}$ and $\mathrm{M}$ chicken strains. Moreover, $\mathrm{Ca}$ and $\mathrm{Ph}$ concentrations were significantly decreased for both experimental chicken strains from eggshell of fresh eggs to eggshell of chicks at hatch and the intermediate concentrations were recorded for eggshells during incubation.
Whereas, $\mathrm{Ca}$ and $\mathrm{Ph}$ concentrations were significantly increased in tibia from embryos at day 15 towards of hatched chicks for both chicken strains. Different authors came to the same conclusion herein that there were significant differences between strains with respect to $\mathrm{Ca}$ and $\mathrm{Ph}$ concentrations either for eggshell or tibia bone (Shafy et al., 1989; and Shahein et al., 2009).

It is observed from the current results that OPN concentration had the same trend of increase in $\mathrm{Ca}$ and $\mathrm{Ph}$ for eggshell and tibia. This observation refers to the substantial relation between OPN with $\mathrm{Ca}$ and $\mathrm{Ph}$ and their behaviors in shell and bone texture. Supporting to this notion, Morcki (2005) reported that eggshell is a primary source of $\mathrm{Ca}$ for embryonic skeleton and bone formation and development. Also, Mazzuco and Bertechini (2014) mentioned that OPN had a major role in mineralization and $\mathrm{Ca}$ metabolism of chicken eggshell. Moreover, Pines (2007) mentioned that OPN concentration is believed to play an important role in the process of bone mineralization by its ability to bind calcium, its localization to electron- dense regions of mineralization and the regulation of its gene expression by calcitrophic hormones such as parathyroid hormone. Furthermore, Hincke et al. (2008) observed that $\mathrm{Ca}$ was mobilized from the eggshell to the developing embryo and incorporated with OPN in eggshell and this process could serve some roles of shell dissolution for providing the embryos with $\mathrm{Ca}$. Also, Dunn et al. (2008) and Hincke et al. (2008) revealed that the specific occlusion of OPN calcite during mineralization may influence eggshell structure and thereby modify its pasture resistance toughness and shell quality.

Data presented in this study regarding the increase of $\mathrm{Ca}$ and OPN could be the reasons for the improvement of eggshell quality for $M$ strain compared to $G$ one in the present results. 
Biochemical parameters: Figure 1 illustrates effect of parental $G$ and $M$ chicken strains with reference to OPN on some parameters of the biochemical plasma and parathyroid hormone in hatched chicks. Mandarah chicks surpassed $(\mathrm{p} \leq 0.05) \mathrm{G}$ ones with respect to plasma $\mathrm{Ca}$ and $\mathrm{Ph}$, globulin, glucose and parathyroid hormone. While, total lipids and cholesterol had opposite trend as they decreased $(p \leq 0.05)$ for $M$ chicks compared with $G$ ones.

The significant differences between plasma biochemical parameters of the hatched chicks could be due to the maternal effect of the both experimental strains as Dixon et al. (2016) mentioned that maternal effects is epigenetic modification of offspring phenotype provided by the mother during development. Latour et al. (1996) mentioned that the observed changes suggest that many of the physiological and biochemical processes function differently in embryos from parents. Also, Dowidar et al. (1999) stated that strain differences have significant effects on the most blood criteria and these differences could be due to genetical causes.

Significant differences were reported between local strains for serum concentrations of cholesterol and blood glucose (Dowidar et al., 1999), serum calcium and globulin (Enaiat et al., 2010) and parathyroid hormone concentration (Hassan et al., 2008). The observed increase of globulin concentration as indication of immune response in the blood of $\mathrm{M}$ hatched chicks could be related to the mentioned of OPN in the mother's blood and in eggshell. This conclusion could be explained on the light of those reported by Sodek et al. (2000) who showed that OPN was involved in a variety processes including immunological response.

The significant increase of egg production for $\mathrm{M}$ hens compared with $\mathrm{G}$ ones could be reflected on the increase of $\mathrm{Ca}, \mathrm{Ph}$ and $\mathrm{PTH}$ hormone for $\mathrm{M}$ chicks and these results are showed that bone is approximately keeping with those reported by Maysa et al. (2006) who mentioned that the $\mathrm{Ca}$ and $\mathrm{Ph}$ absorption was significantly higher in the high egg production hens than the low egg production one. Also, Preda et al. (2013) found that higher production of eggs induces an increase in the plasma concentration of calcium. The obtained results of increasing plasma $\mathrm{Ca}, \mathrm{Ph}$ and PTH levels related to the increase of $\mathrm{Ca}$ and $\mathrm{Ph}$ levels in eggshell (Table 3) and eggshell quality (Table 2) and OPN concentration (Table 1) are in harmony with those previously mentioned by Jiang et al. (2010) and Preda et al. (2013) who found that the increase of PTH concentration was parallel with the plasma calcium level and PTH controls $\mathrm{Ca}$ and $\mathrm{Ph}$ level of blood and maintains the $\mathrm{Ca}$ homeostasis by regulating $\mathrm{Ca}$ liberation from the bone. Furthermore, Noda and Rodan (1989) and Lavelin et al. (2000) revealed that calcitrophic substance such as PTH hormone had regulation effect on OPN gene expression. Moreover, Jiang et al. (2010) cleared that better eggshell quality and breaking strength could be due to the higher blood $\mathrm{Ca}$, OPN and PTH.

Bone strength: It is clear from Figure 3 that the tibia bone of embryos at day 15 and hatched chicks are stronger $(p \leq 0.05)$ for $M$ chicken strain than those for $G$ one. The tibia bon strength for embryos of $M$ strain was 4.83 Newton compared with 4.11 for $\mathrm{G}$ strain and for hatched chicks were 7.32 and 6.41 Newton for $M$ and $G$ strains, respectively. The statistical differences of bone strength between chicken strains were noticed by Rayan et al. (2013). The significant increase of $M$ tibia bone strength compared to those of $\mathrm{G}$ one could be related to the increase of OPN concentration in tibia bone (Table 1), tibia ca and $\mathrm{Ph}$ concentrations (Table4) and plasma levels of $\mathrm{Ca}, \mathrm{Ph}$ and PTH (Fig. 1). Supporting to these relations,Moreki(2005)and Silversides et al. (2006) 
composed of $70 \%$ minerals, $20 \%$ organic matter and $10 \%$ water besides; calcium phosphate makes up about $80 \%$ of mineral matter and provides the structural of bone. Rayan et al. (2013) mentioned that $\mathrm{Ca}$ and $\mathrm{Ph}$ contribute to the bone strength and stiffness. Also, Moreki (2005) reported that PTH hormone enhances bone remodeling, promotes cartilage maturation and determine the amount of $\mathrm{Ca}$ and $\mathrm{Ph}$ built into the bone. Moreover, Rath et al. (2000) reported that bone strength and quality not depend only on inorganic matrix but also on organic matrix. Finally, Ibelli et al. (2013) showed that OPN concentrations could play an important role in bone remodeling and mineralization.

Mitotic index: Figure 3. illustrates mitotic index (MI) in tibia of embryos at day 15 and for hatched chicks for $\mathrm{G}$ and $\mathrm{M}$ strains. Mitotic indices as indicator of cell multiplication in tibia did not represent any significant change between both experimental strains. Mandarah chicken strain possess as a numerical increase of MI for tibia of embryos and hatched chicks compared to those for $\mathrm{G}$ one.The numerical increase of MI for tibia bone of M chickens compared to $G$ ones with respect to embryos at day 15 and hatched chicks could explain the previous mentioned results of earlier hatch for $M$ chicks. This related change of mitotic indices with early hatch and fasting development of embryonic cells added credence to that reported by Hamburger and Hamilton (1951) who mentioned that white leghorn embryos developed faster than Brred Plymouth Rock and the genetic differences is the reason factor of the embryonic development of different breeds. Also, Dondua et al. (1966) referred that mitotic index is an indication to proliferation activity and development at embryonic stages. Moreover, Steel (1977) stated that rapid proliferation of cells was accompanied by a high mitotic index and vice for embryonic development.

\section{IN CONCLUSION,}

the obtained results from this study may contribute for better understanding of the mineralization process with reference to osteopontin protein and its role on eggshell quality, bone strength, hatching output and calcification of eggshell and bones focusing on their relations with chicken strain. Thus we hope that geneticists could use the criterion of osteopontin detection in the future strategies for improving eggshell quality and hatchability. 
Table (1): Osteopontin protein concentration $(\mathrm{ng} / \mu \mathrm{L})$ in eggshell, embryonic tibia and blood of hatched chicks of Gimmizah and Mandarah strains

\begin{tabular}{|c|c|c|c|c|c|c|c|}
\hline \multirow{4}{*}{ Chicken strain } & \multicolumn{7}{|c|}{ Osteopontin concentration $n g / \mu \mathrm{L}$} \\
\hline & \multicolumn{4}{|c|}{ Eggshell } & \multicolumn{2}{|c|}{ Tibia } & \multirow{3}{*}{$\begin{array}{c}\text { hatched chick's } \\
\text { blood }\end{array}$} \\
\hline & \multirow[t]{2}{*}{ Fresh eggs } & \multicolumn{2}{|c|}{ During incubation } & \multirow[t]{2}{*}{ At hath } & \multirow{2}{*}{$\begin{array}{l}15^{\text {th }} \text { day of } \\
\text { incubation }\end{array}$} & \multirow{2}{*}{ Hatched chicks } & \\
\hline & & $9^{\text {th }}$ day & $15^{\text {th }}$ day & & & & \\
\hline Gimmizah & $15.70 \pm 0.11^{\mathrm{bA}}$ & $13.98 \pm 0.59^{\mathrm{B}}$ & $12.22 \pm 0.16^{\mathrm{B}}$ & $8.37 \pm 0.11^{\mathrm{bC}}$ & $9.71 \pm 0.34^{\mathrm{B}}$ & $11.89 \pm 0.05^{\mathrm{bA}}$ & $12.66 \pm 0.15^{\mathrm{b}}$ \\
\hline Mandarah & $16.95 \pm 0.30^{\mathrm{aA}}$ & $14.25 \pm 0.47^{\mathrm{B}}$ & $13.70 \pm 0.13^{\mathrm{B}}$ & $9.21 \pm 0.06^{\mathrm{aC}}$ & $10.05 \pm 0.20^{\mathrm{B}}$ & $14.57 \pm 0.09^{\mathrm{aA}}$ & $13.15 \pm 0.17^{\mathrm{a}}$ \\
\hline
\end{tabular}

$\mathrm{a}$ and $\mathrm{b}$ means having different letters in the same column are significantly different $(\mathrm{P} \leq 0.05)$.

$\mathrm{A}, \mathrm{B}$ and $\mathrm{C}$ means having different letters in the same row within the same trait are significantly different $(\mathrm{P} \leq 0.05)$.

Table (2): Effect of chicken strain with reference to osteopontin protein on eggshell quality parameters

\begin{tabular}{|c|c|c|c|c|c|c|c|c|}
\hline \multirow[b]{2}{*}{$\begin{array}{l}\text { Chicken } \\
\text { strain }\end{array}$} & \multicolumn{8}{|c|}{ Eggshell quality parameters } \\
\hline & $\begin{array}{l}\text { Abnormal } \\
\text { eggs \% }\end{array}$ & $\begin{array}{l}\text { Egg weight } \\
\text { (g) }\end{array}$ & $\begin{array}{c}\text { Eggshell } \\
\text { weight }(g)\end{array}$ & $\begin{array}{l}\text { Eggshell } \\
\text { weight } \%\end{array}$ & $\begin{array}{c}\text { Shell } \\
\text { strength } \\
\text { (Newton) }\end{array}$ & $\begin{array}{l}\text { Eggshell } \\
\text { index }\end{array}$ & $\begin{array}{c}\text { Eggshell } \\
\text { thickness }(\mathrm{mm})\end{array}$ & $\begin{array}{c}\text { Eggshell } \\
\text { membranes } \\
\text { thickness(mm) }\end{array}$ \\
\hline Gimmizah & $11.58 \pm 0.54^{\mathrm{a}}$ & $52.71 \pm 0.02^{\mathrm{a}}$ & $6.22 \pm 0.12^{\mathrm{b}}$ & $10.66 \pm 0.22^{\mathrm{b}}$ & $23.41 \pm 0.22^{b}$ & $75.64 \pm 0.30^{b}$ & $0.34 \pm 0.003^{b}$ & $0.04 \pm 0.001^{\mathrm{b}}$ \\
\hline Mandarah & $9.10 \pm 0.47^{\mathrm{b}}$ & $51.35 \pm 0.02^{\mathrm{b}}$ & $6.66 \pm 0.08^{\mathrm{a}}$ & $12.96 \pm 0.15^{\mathrm{a}}$ & $24.26 \pm 0.37^{\mathrm{a}}$ & $77.71 \pm 0.29^{\mathrm{a}}$ & $0.35 \pm 0.003^{\mathrm{a}}$ & $0.05 \pm 0.001^{\mathrm{a}}$ \\
\hline
\end{tabular}

$\mathrm{a}$ and $\mathrm{b}$ means having different letters in the same column are significantly different $(\mathrm{P} \leq 0.05)$ 
Table (3): Effect of chicken strain with reference to osteopontin protein on egg weight loss, embryonic mortality, hatch time, hatchability and chick weight

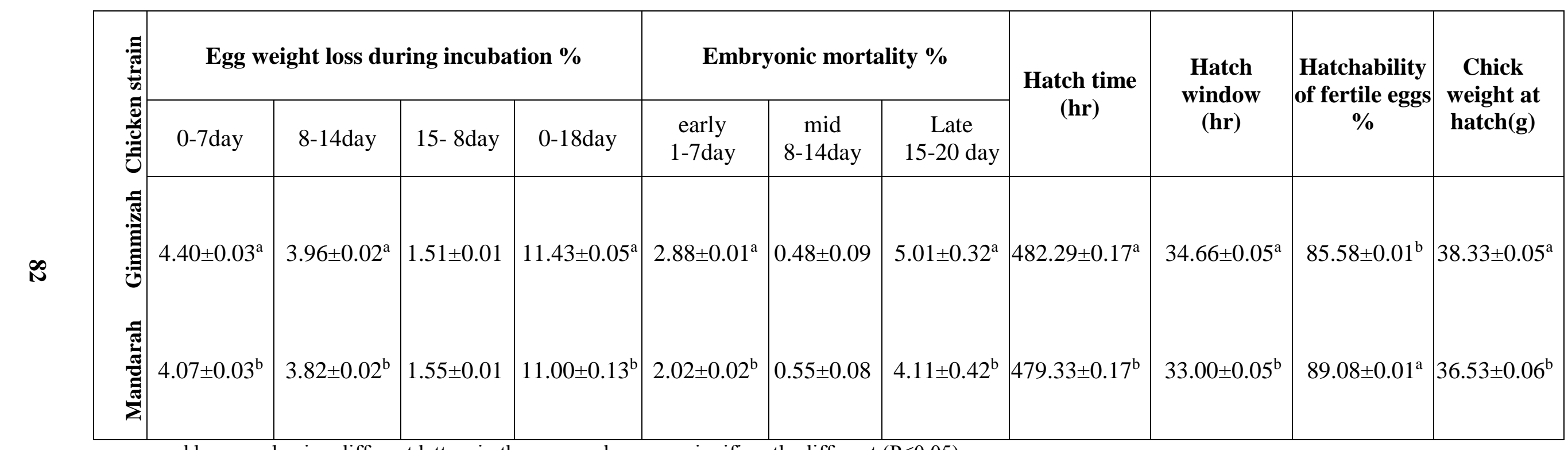

$\mathrm{a}$ and $\mathrm{b}$ means having different letters in the same column are significantly different $(\mathrm{P} \leq 0.05)$. 
Table (4): Effect of chicken strain with reference to osteopontin protein on calcium and phosphorus concentrations in eggshell and tibia

\begin{tabular}{|c|c|c|c|c|c|c|}
\hline \multirow{3}{*}{$\begin{array}{l}\text { Chicken's } \\
\text { age stage }\end{array}$} & \multicolumn{4}{|c|}{ Eggshell } & \multicolumn{2}{|c|}{ Tibia } \\
\hline & \multirow[t]{2}{*}{ Fresh eggs } & \multicolumn{2}{|c|}{ during incubation } & \multirow[t]{2}{*}{ At hath } & \multirow{2}{*}{$\begin{array}{c}\text { embryos at } \\
15^{\text {th }} \text { day }\end{array}$} & \multirow[t]{2}{*}{ hatched chicks } \\
\hline & & $9^{\text {th }}$ day & $15^{\text {th }}$ day & & & \\
\hline \multirow{4}{*}{$\begin{array}{l}\text { Gimmizah } \\
\text { Mandarah }\end{array}$} & \multicolumn{6}{|c|}{ Calcium } \\
\hline & $11.92 \pm 0.32^{\mathrm{bA}}$ & $10.58 \pm 0.03^{\mathrm{bB}}$ & $9.85 \pm 0.03^{\mathrm{bC}}$ & $9.51 \pm 0.09^{\mathrm{D}}$ & $9.34 \pm 0.03^{\mathrm{B}}$ & $9.72 \pm 0.03^{\mathrm{A}}$ \\
\hline & $13.05 \pm 0.02^{\mathrm{aA}}$ & $11.97 \pm 0.07^{\mathrm{aB}}$ & $10.28 \pm 0.07^{\mathrm{aC}}$ & $9.81 \pm 0.07^{\mathrm{D}}$ & $9.38 \pm 0.05^{\mathrm{B}}$ & $9.84 \pm 0.05^{\mathrm{A}}$ \\
\hline & \multicolumn{6}{|c|}{ Phosphorus } \\
\hline Gimmizah & $5.23 \pm 0.08^{\mathrm{bA}}$ & $4.37 \pm 0.08^{\mathrm{bB}}$ & $4.06 \pm 0.08^{\mathrm{bC}}$ & $3.52 \pm 0.01^{\mathrm{D}}$ & $4.23 \pm 0.03^{\mathrm{B}}$ & $4.71 \pm 0.10^{\mathrm{A}}$ \\
\hline Mandarah & $5.29 \pm 0.08^{\mathrm{aA}}$ & $4.74 \pm 0.07^{\mathrm{aB}}$ & $4.40 \pm 0.08^{\mathrm{aC}}$ & $3.74 \pm 0.08^{\mathrm{D}}$ & $4.49 \pm 0.01^{\mathrm{B}}$ & $4.86 \pm 0.11^{\mathrm{A}}$ \\
\hline
\end{tabular}
$\mathrm{a}$ and $\mathrm{b}$ means having different letters in the same column are significantly different $(\mathrm{P} \leq 0.05)$.

$\mathrm{A}, \mathrm{B}, \mathrm{C}$ and $\mathrm{D}$ means having different letters in the same row within each trait are significantly different $(\mathrm{P} \leq 0.05)$. 
Mona R. M. Ahmed et al.

Figure (1): Effect of parental Gimmizah (G) and Mandarah (M) chicken strains with reference to osteopontin protein on some plasma biochemical parameters and parathyroid hormone of hatched chicks
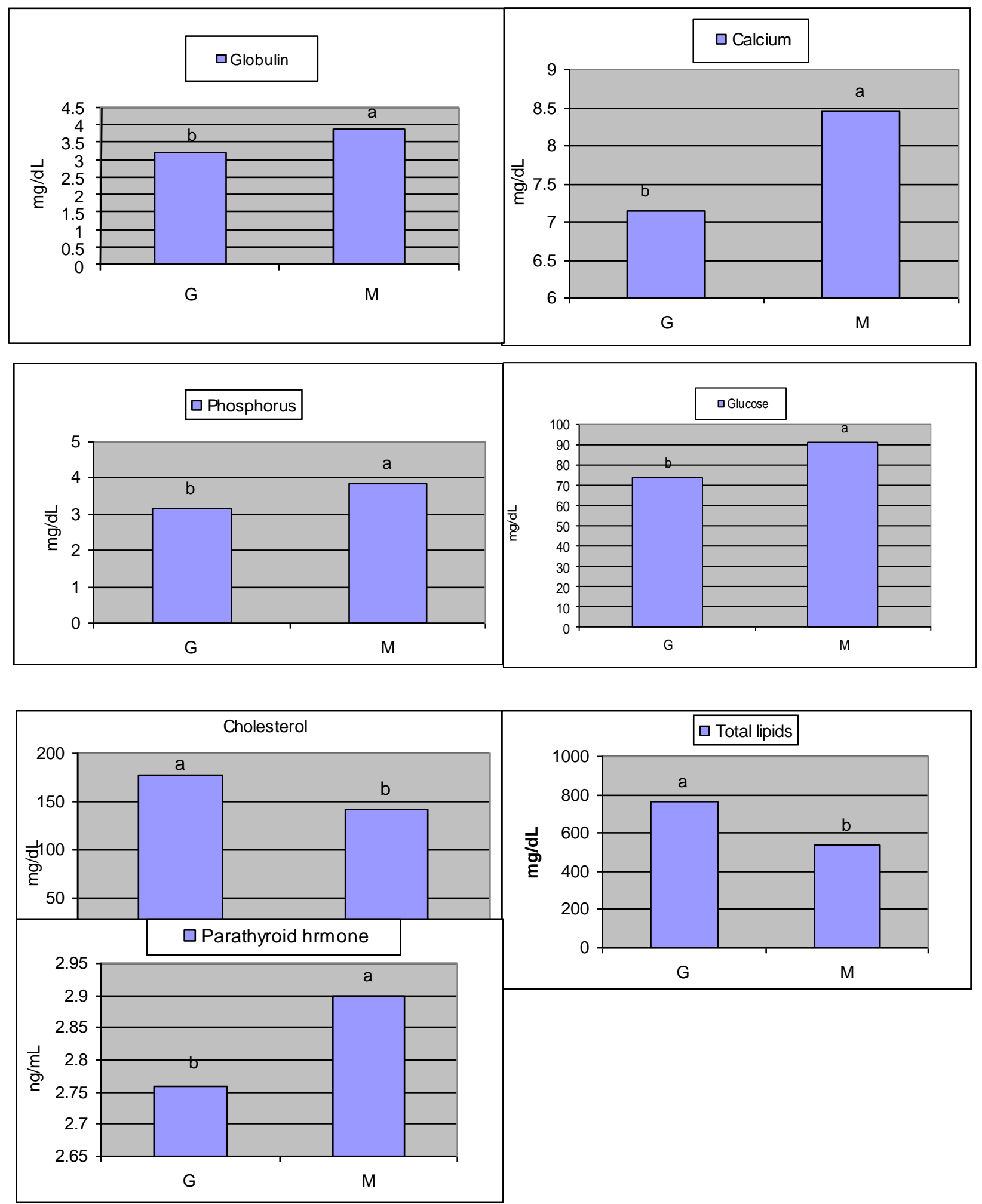
Figure (2): Effect of Gimmizah (G) and Mandarah (M) chicken strains with reference to osteopontin protein on tibia bone strength of embryos and hatched chicks

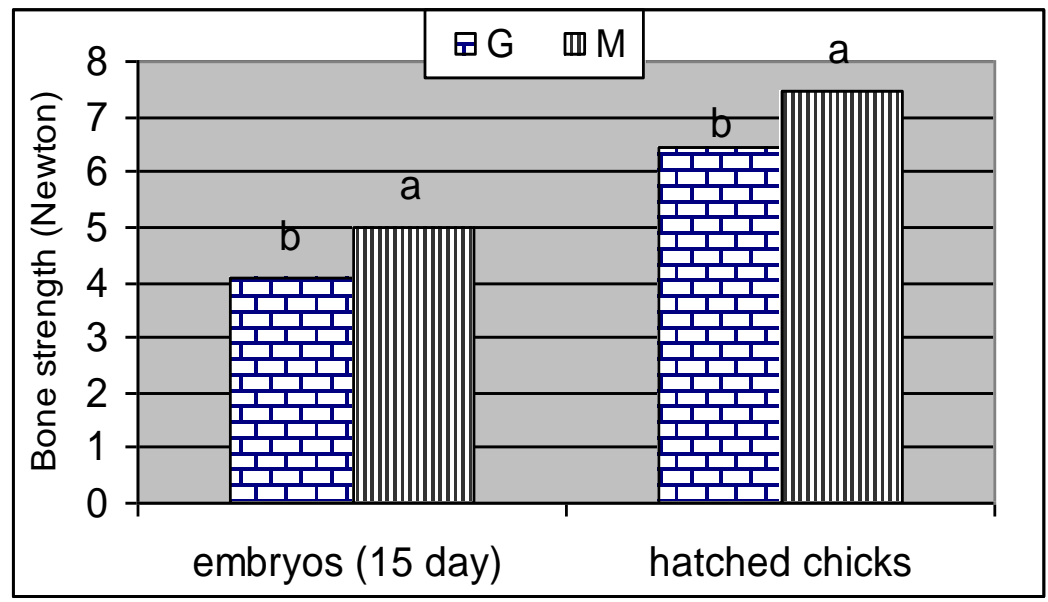

Figure (3): Effect of Gimmizah (G) and Mandarah (M) chicken strains with reference to osteopontin protein on Mitotic index of tibia bone for embryos and hatched chicks

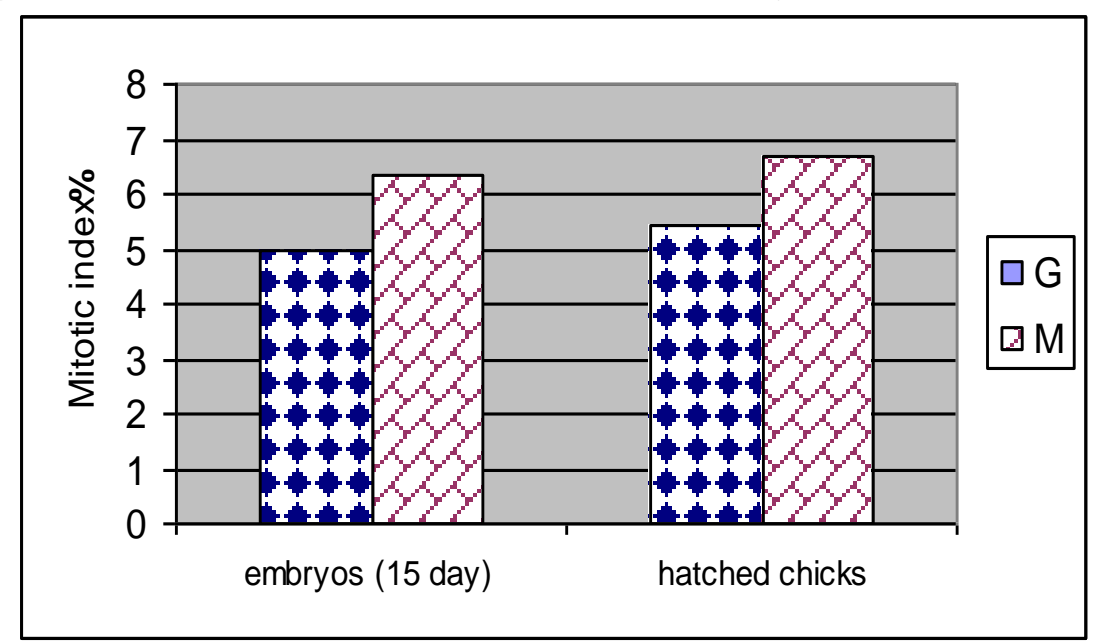




\section{REFERENCES}

Arias, J. L.; and Fernandez, M. S., 2001. Role of extracellular matrix molecules in shell formation and structure. World's Poult. Sci. J., 57: 349-357.

AOAC, Association of Official Agricultural Chemists. 1955. Official Methods of Analysis. 8th ed. Association of Official Agricul-tural Chemists, Washington, DC.

AOAC, Association of Official Analytical Chemists. 1998. Official Meth-ods of Analysis. $16^{\text {th }}$ ed. AOAC International, Gaithers- burg, MD.

Bennett, J. K.; Ringer, R. K.; Bennett, R. S.; Williams brea, B. A.; and Humphrey, P. E., 1988. Comarison of breaking strength and shell thickness as evaluators of eggshell quality. Environ. Toxicol. Chem., 7: 351-357.

Brake, J., 1998. Relationship of time of feeding and strain to eggshell quality and hatchability in broiler breeders. Poult. Sci., 67: 144-151.

Christensen, V. L.; Noble, D. O.; and Nestor, K. E., 2000. Influence of selection for increased body weight, egg production, and shank width on the length of the incubation period of turkey. Poult. Sci., 79: 613-618.

Decuypere, E.; Tona, K.; Bruggeman, V.; and Bamelis, F., 2001. The day-old chick : a crucial hinge between breeders and broiler. World's Poult. Sci. J., 57: 127-138.

De Ketelaere, B.; Govaerts, T.; Coucke, P.; Dewil, E.; Visscher, J.; Decuypere, E.; and De Baerdemaeker, J., 2002. Measuring the eggshell strength of 6 different genetic strains of laying hens: Techniques and comparisons. Br. Poult. Sci., 34: 238244.

Dixon, L. M.; Sparks, N. H. C.; and Rutherford, K. M. D., 2016. Early experiences matter: a review of the effects of prenatal environment on offspring characteristics in poultry. Poult. Sci., 95: 489-499
Dohnal, J. M.; Kielczewski, K.; Pospiech, M.; and Lakota, P., 1989. Genetic relationship between egg shell quality and hatchability of eggs from laying hens. In Polish, summary in English. Zeszyty Naukowe Drobiarstwa, 6: 5-11.

Dominguez-Vera, J. M.; Gautron, J.; Garcia-Ruiz, J.; and Nys, Y., 2000. The effect of avian uterine fluid on the growth behavior of calcite crystals. Poult. Sci., 79: 901-907.

Dondua, A. K.; Efremov, V. I.; Krichinskaya, E. B.; and Nikolaeva, I. P., 1966. Mitotic index, duration of mitosis and proliferation activity in the early phases of the development of the chick embryo. Acts Biol. Hung., 17: 127-143.

Dowidar, Y. A.; Nofal, R. Y.; and Afifi, Y. K., 1999. Carcass and some serum biochemical traits of males of three local Egyptian chicken srains. Egypt. Poult. Sci., 19: 395-406.

Duncan, D. B., 1955. Multiple range and multiple F tests. Biometrics 11: 1-42.

Dunn, I. C.; Joseph, N. T.; Bain, M.; Edmond, A.; Wilson, P. W.; Milona, P.; Nys, Y.; Gautron, J.; Schmutz, M.; Preisinger, R.; and Waddington, D., 2008. Polymorphisms in eggshell organic matrix genes are associated with eggshell quality measurements in pedigree Rhode Island Red hens. Anim. Gene., 40: 110-114.

Enaiat, M. M. El-Anawer; Amina, A. Salem; and Eman, M. Abou-Eitta, 2010. A comparative study of productive and physiological performance between two local strains of chicks. Egypt. Poult. Sci., 30: 297316.

Fathi, M. M.; Yousria, K. Afifi; and ElSafty, S. A., 2010. Ultrastructural diversity of eggshell quality in some Egyptian local breeds of chicken. Egypt. Poult. Sci., 30: 813-827.

Fernandez, M. S.; Escobar, C.; Lavelin, I.; Pines, M.; and Arias, J. L., 2003. Localization of osteopontin in oviduct 
tissue and eggshell during different stages of the avian egg laying cycle. J. Struct. Biol., 143: 171-180.

Hamilton, H. L., 1952. Lillie's Development of the Chick: An Introduction to Embryology. Holt, Reinhart and Winston, New York, pp: 70-91.

Hassan, M. S. H.; Abdalla, E. A.; Abdel Samed, M. H., 2008. Physiological and immunological roles of acetic acid for improving egg production and decreasing pollution and ammonia level in local laying hens houses. Egypt. Poult. Sci., 28: 223-250.

Hincke, M. T.; Chien, Y. C.; Gerstenfeld, L. C.; and McKee, M. D., 2008. Colloidal-gold immunocytochemical localization of osteopontin in avian eggshell gland and eggshell. J. Histochem. Cytochem, 56: 167-176.

Hincke, M. T.; Nys, Y.; Gautron, J.; Mann, K.; Rodriguez-Navarro, A. B.; and McKee, M., 2012. The eggshell: structure, composition and mineralization. Frontiers Biosci., 17: 1266-1280.

Ibelli, A. M. G.; Fornari, M. B.; Neis, K. L.; Zanella, R.; Tessmann, A. L.; Pandolfi, J. R. C.; Cantão, M. E.; Ledur, M. C.; and Peixoto, J. O., 2013. Associations of the osteopontin gene with performance traits in a paternal broiler line. Resumos do 59 Congresso Brasileiro de Geneticia . 16 a 19 de setembro.

Jiang, R. S.; Xie, Z.; Chen, X. Y.; and Geng, Z. Y., 2010. A single nucleotide polymorphism in the parathyroid hormone gene and effects on eggshell quality in chickens . Poult. Sci., 89: 2101-2105.

Jonchere, V.; Sophie Antier, C.; Cabau, C.; Sibut, V.; Cogburn, L.; Nys, Y.; and Gautron, J., 2010. Gene expression profiling to identify eggshell protiens involved in physical defense of the chicken egg. BMC Genomics, 11: 57 $-66$.
Juliet, R. Roberts, 2004. Factors affecting egg internal quality and egg shell quality in laying hens. J. Poult. Sci., 41: 161177.

Krystianiak, S.; Nowaczewski, S.; and Kontecka, H., 2016. How important is eggshell colour im ring-necked pheasant (Phasianus colchicus L.) reproduction? Part I- Morphological, physical feature of egg and eggshell quality. World's Poult. Sci. J., 72: 323-331.

Latour, M. A.; Peebles, E. D.; Boyle, C. R.; Doyle, S. M.; Pansky, T.; and Brake, J. D., 1996. Effects of Breeder Hen Age and Dietary Fat on Embryonic and Neonatal Broiler Serum Lipids and Glucose. Poult. Sci., 75: 695-701.

Lavelin, I.; Meiri, N., and Pines, M., 2000. New insight in eggshell in formation. Poult. Sci., 79: 1014-1017.

Mahrous, M. Y.; Radwan, L. M.; and ElDlebshany, A. E., 2013. Shell quality and ultrastructural characteristics of eggshell in the $15^{\text {th }}$ generation of chickens selected for egg production traits. Egypt. J. Anim. Prod., 50: 13-18.

Mann, K.; and Mann, M., 2013. The proteome of the calcified layer organic matrix of turkey (Meleagris gallopavo) eggshell. Proteome Sci., 11: 40-55.

Maysa, M. Hanafy; El-Sheikh, A. M. H.; and Hanaa, M. Khalil, 2006. In vivo study of intestinal calcium and phosphorus absorption during different stages of egg formation in the reproductive tract of high and low egg production laying hens. Egypt. Poult. Sci., 26: 319-334.

Mazzuco, H.; and Bertechini, A. G., 2014. Critical points on egg production: importance and incidence of eggshell breakage and defects. Cienc. Agrotec. Lavars, 38: 7-14.

Mona, R. M., 2011. Effect of disinfection on embryonic development, hatchability characteristics and post-hatch productive performance in local chickens. Ph. D. Thesis, Fac. Of Agric., (SabaBacha) Alexandria Univ. Egypt. 
Mona, R. M. Ahmed; Wesam, A. Fares; Rizk, R. E.; and Abdalla, E. A., 2016. Skeletal embryonic development and hatching traits as affected by eggshell osteopontin protein during two stages of laying cycle. Egypt. Poult. Sci., 36: 805823.

Moreki, J. C., 2005. The influence of calcium intake by broiler breeders on bone development and egg characteristics. Ph.D. Thesis, Fac. of Natural and Agricultural Sciences. University of the Free State.

Noda, M.; and Rodan, G. A., 1989. Transcriptional regulation of osteopontin production in rat osteoblastlike cells by parathyroid hormone. J. Biol. Chem., 108: 713-718.

Nys, Y.; Gautron, J.; Garcia-Ruiz, J. M., and Hincke, M. T., 2004. Avian eggshell mineralization: biochemical and functional characterization of matrix proteins.CR Palevol., 3: 549-562.

Nys, Y.; Hincke, M. T.; Arias, J. L.; Garcia-Ruiz, J. M.; and Soliman, S. E., 1999. Avian eggshell mineralization. Poultry Avian Biol. Res. 10: 142-166.

Overton, J. 1958. Effect of colchicne on the early chicks blastoderm. J. Exp. Zool., 139: 329-347.

Park, S.; Birkhold, S.; Kubena, L.; Nisbet, D.; and Ricke, S., 2003. Effect of storage condition on bone breaking strength and bone ash in laying hens at different stages in production cycles. Poult. Sci., 82: 1688-1691

Pines, M., 2007. The involvement of matrix protein in eggshell formation. Aust. Poult. Sci. Symp., 130-133.

Preda, C.; Balaceanu, R.; and Dojana, N., 2013. Evolution of hormonal control of calcium and phosphorus metabolism in different hens breeds during the laying cycle. Vet. Med., 70: 286-292.

Rahn, H., 1981. Gas exchange of avian eggs with special reference to turkey eggs. Poult. Sci., 60: 1971-1980.
Rahn, H.; Ar, A.; and Paganelli, C. V., 1979. How bird eggs breathe. Sci. Am., 240: 38-47.

Rath, N. C.; Huff, G. R.; Huff, W. E.; and Balog, J. M., 2000. Factors regulating bone maturity and strength in poultry. Poult. Sci., 79: 1024-1032.

Rayan, G. N.; Galal, A.; Fathi, M. M.; and El-Attar, A. H., 2013. Effect of layer breeder strain and age on tibia bone characteristics of chicks. J. Agri. Vet. Sci., 6: 111-124.

Rizk, R. E., 1994. Influence of chicken egg abnormalities on embryonic development and hatchability. Egypt. Poult. Sci., 14: 317-337.

Rizk, R. E.; Nadia, A. EL-Sayed; Shahein, E. H. A.; and Hedaia, M. Shalan, 2008. Relationship between eggshell membranes and embryonic development through different egg production periods in two developed chicken strains. Egypt. Poult. Sci., 28: 535- 551.

Romanoff, A. L.; and Romanoff, A. J., 1949. The avian egg. John Wiely and Sons . Inc. New York.

SAS., 2004. SASISTAT Users Guide. Version 9.1 . SAS Inst. I.C., Carry,Nc,USA.

Scott, T. A.; and Silversides, F. G., 2000. The Effect of storage and strain of hen on egg quality. Poult. Sci., 79: 17251729.

Shafy, T. M.; McDonald, M. W.; and Pym, R. A., 1989. Effects of dietary calcium, available phosphorus and vitamin $\mathrm{D}$ on growth rate, food utilization, plasma and bone constituents and calcium and phosphorus retention of commercial broiler strain. Brit. Poult. Sci., 31: 587-602.

Shahein, S. H. A., 2002. Factors affecting hatchability and their relation to embryonic development in local chicken strains. Ph. D. Thesis, Fac. Of Agric., Kafr El-Sheikh, Tanta University, Egypt. 
Shahein, E. H. A.; Moawed, M.; and Amany, A. El-Sahn, 2009. Hatching power of some developed chicken srains in relation to minerals concentration in eggshell membranes.1- physical mobilization of minerals in eggshell membranes. Egypt. Poult. Sci., 29: 423438.

Silversides, F. G.; Korver, D. R; and Budgell, K. L., 2006. Effect of strain of layer and age at photostimulation on egg production, egg quality, and bone strength. Poult. Sci., 85: 1136-1144.

Sodek, J.; Ganss, B.; and McKee, M. D., 2000. Osteopontin. Crit. Rev. Oral Biol. Med., 11: 279-303.

Steel, G. G., 1977. "Growth kinetics of tumours, cell population kinetics in relation to the growth and treatment of cancer" Clarendin press. Oxford.

Suarez, M.; Wilson, H. R.; Mather, F. B.; Wilcox, C. J.; and McPherson, B. N., 1997. Effect of strain and age of broiler breeder female on incubation time and chick weight. Poult. Sci., 76: 1029-1036.

Tona, K.; Onagbesan, O.; De Ketelaere, B.; Decuypere, E.; and Bruggeman, V., 2004. Effects of age of broiler breeders and egg storage on egg quality hatchability, chicks quality, chick weight, and chick posthatch growth to forty -two days. Appl. Poult. Res., 13: $10-18$.
Weinreb, M.; Shinar, D.; and Rodan, G. A., 1990. Different pattern of alkaline phosphatase, osteopontin and osteocalcin expression in developing rat bone visualized by in situ hybridization. J. Bone Miner. Res., 5: 831-842.

Wesam, A. Fares; Mona, R. M. Ahmed; Rizk, R. E.; and Shahein, E. H. A., 2015. Effect of eggshell conductance constant on embryonic intestine function, hatching characters and subsequent growth for developed chickens and its relation with 1Hatching eggs storage. Egypt. Poult. Sci., 35: 875-893.

Younis, H. H.; and Abd El-Ghany, 2003. Productive and reproductive performance of four local chicken strains during winter and summer seasons. Egypt. Poult. Sci., 23: 893-910.

Yousria, K. Afifi; Nazla, Y. Abou ElElla; Hanan, H. Ghanem; Aly, O. M.; and Magda, M. Balat, 2010. Factors affecting hatching traits and posthatching growth in two developed chicken strains. Egypt. Poult. Sci., 30: 157-177.

Yuan, K.; Guangbing, W.; Matilda, U.; Bryant, M.; and Roland, D. A. Sr., 2009. Effect of dietary energy on performance, egg component, egg solids and egg quality in bovans white and deklep white hens during phase 2. J. Poult. Sci., 46: 30-34. 


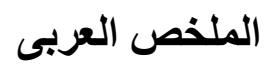

تأثير بروتين الاستيوبونتين فى قثرة البيض على تطور الجهاز العظمى الجنينى و صفات الفقس فى القي

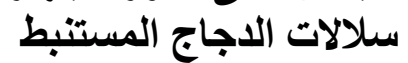

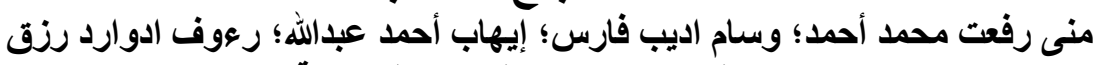

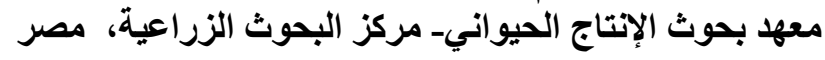

تم إجر اء هذا البحث لدر اسة تأثير سلالة الدجاج (المندرة والجمبزة) وبروتين الأوستيوبونتين الموجود فى قثرة البيض وقيض

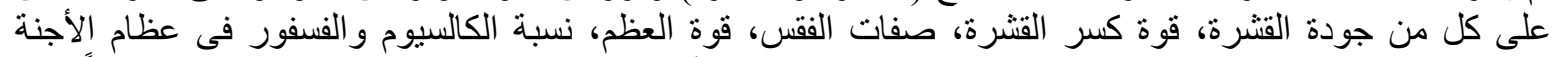

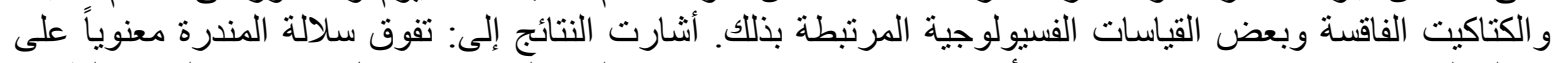

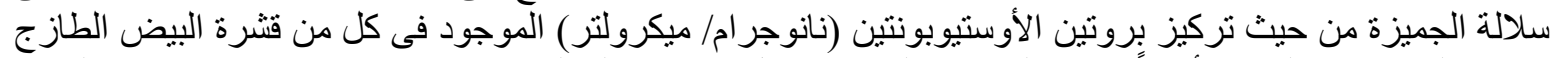

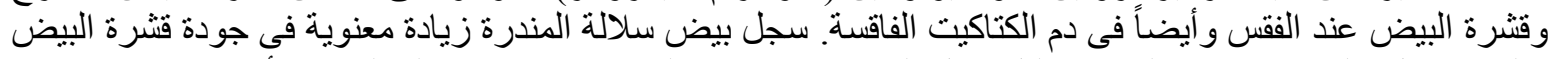

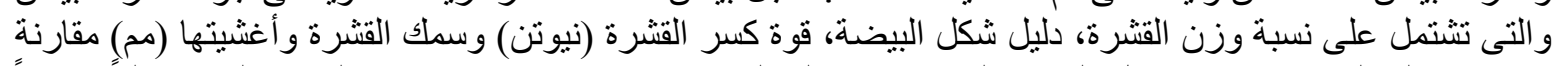

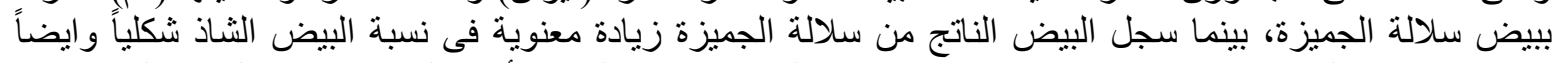

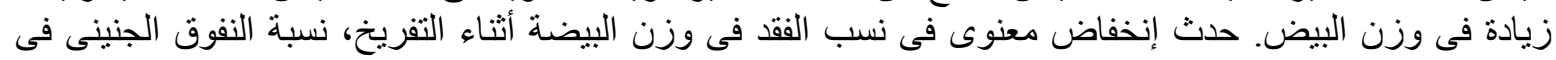

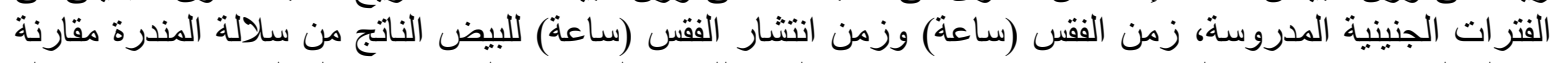

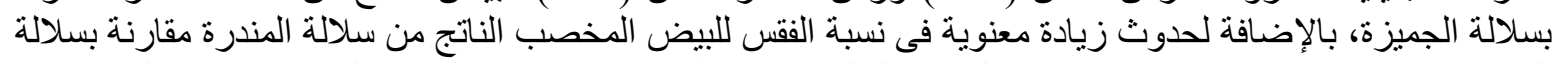

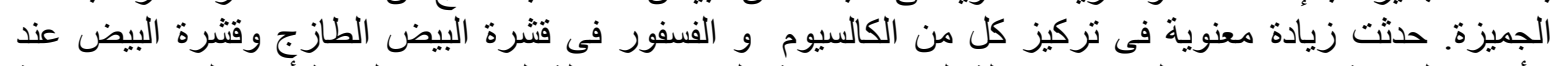

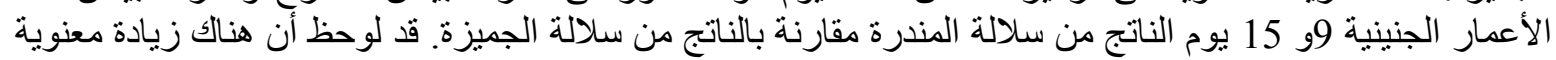

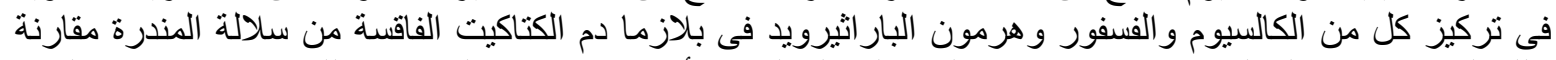

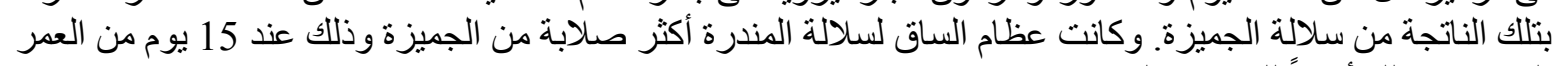
الجنينى وكذللك أيضاً للكتاكيت الفاقسة الجنة.

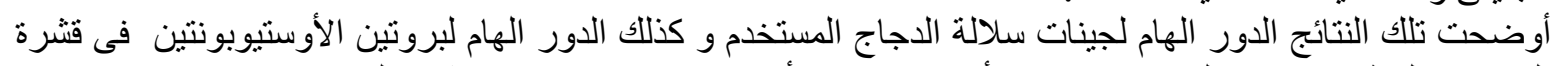

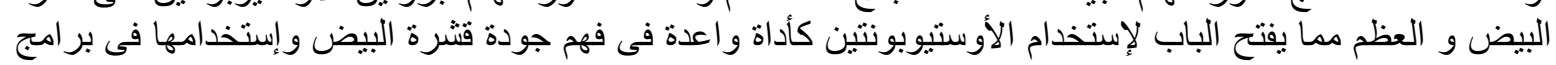
التربية والإنتخاب. 